\title{
Antecedents and consequences of effectuation and causation in the international new venture creation process
}

\author{
Rainer Harms • Holger Schiele
}

Published online: 17 March 2012

(C) The Author(s) 2012. This article is published with open access at Springerlink.com

\begin{abstract}
The selection of the entry mode in an international market is of key importance for the venture. A process-based perspective on entry mode selection can add to the International Business and International Entrepreneurship literature. Framing the international market entry as an entrepreneurial process, this paper analyzes the antecedents and consequences of causation and effectuation in the entry mode selection. For the analysis, regression-based techniques were used on a sample of 65 gazelles. The results indicate that experienced entrepreneurs tend to apply effectuation rather than causation, while uncertainty does not have a systematic influence. Entrepreneurs using causation-based international new venture creation processes tend to engage in export-type entry modes, while effectuation-based international new venture creation processes do not predetermine the entry mode.
\end{abstract}

Keywords Causation · Effectuation · Entry mode selection · Gazelles · International entrepreneurship $\cdot$ Internationalization

\section{Introduction}

Internationalization is of prime importance for ventures. Internationalization decisions entail commitment, are difficult to change, and have long-term consequences (potentially positive as well as negative) for the firm (Morschett et al. 2010). Therefore, research on the internationalization process has become an important

R. Harms $(\square)$

NIKOS, University of Twente, Postbus 217, 7500 AE Enschede, The Netherlands

e-mail: r.harms@utwente.nl

H. Schiele

OOHR, University of Twente, Postbus 217, 7500 AE Enschede, The Netherlands

H. Schiele

e-mail: h.schiele@utwente.nl 
stream in both the International Business (IB) (Werner 2002) and the International Entrepreneurship (IE) literatures (Keupp and Gassmann 2009).

Within the IB literature, conceptual models aiming to understand the internationalization process are increasingly starting to include entrepreneurship as a key element in this process. Based on Johanson and Vahlne's (1977) seminal model, Johanson and Vahlne (2009) extend their model by explicitly including opportunity creation and recognition to accommodate the increasing acknowledgment of opportunities for international venturing. The most recent addition to the Johanson and Vahlne's model explicitly incorporates elements of entrepreneurship (Schweizer et al. 2010) into the internationalization process.

In the IE literature, conceptual models aiming to understand the entrepreneurial process are moving towards the application of their models to international rather than domestic entrepreneurship. The importance of entrepreneurship in understanding internationalization processes was also recognized by Jones and Coviello (2005), who propose that internationalization is a "time-based process of entrepreneurial behavior" (p. 284). Their model explicitly interprets the internationalization process as a primarily entrepreneurial process, that is, the temporal sequence of "all the functions, activities, and actions associated with perceiving opportunities and creating organizations to pursue them" (Bygrave 2004, p. 2). In addition, they highlight that it is not only a firm's internationalization process over time (establishment chain) that can be analyzed as an entrepreneurial process, but also the process that leads to a particular international market entry (Jones and Coviello 2005).

Sarasvathy (2001) identified two distinct approaches in describing entrepreneurial processes, namely, causation and effectuation (C\&E). Causation has connotations of rational planning (ex ante), whereas effectuation is associated with (ex post) emergent strategies. Sarasvathy illustrates that the choice of either causation or effectuation affects the type of opportunities that are finally exploited: For example, entrepreneurs choosing causation tend to rule out opportunities that do not lend themselves to ex ante planning. Likewise, the choice between C\&E can also impact on international opportunities. This illustrates the wider point that decision-making processes do influence the types of decisions made, and ultimately, their effectiveness (Dean and Sharfman 1996). This makes the analysis of C\&E in general in entrepreneurial processes in particular relevant to international new venture creation processes (INVC processes).

While both IB and IE literatures are increasingly addressing effectuation in internationalization, quantitative research on this subject seems underdeveloped, owing to the fact that C\&E have only recently been operationalized (Chandler et al. 2009; Moroz and Hindle 2012; Perry et al. 2012). Thus, this paper seeks to empirically test key antecedents and consequences of causation- and effectuation-based decision-making processes in the INVC process, with the goal of adding to scholarly understanding of internationalization processes. This research contributes to IE and IB research in the following ways. Firstly, it builds on the idea of the behavioral process as a common foundational element of both entrepreneurship and IB literature. Thereby, this analysis takes a step in the direction of integrating IE and IB research (Jones and Coviello 2005). Secondly, this paper is among the first to apply operationalizations of C\&E (Brettel et al. 2012) and the first to apply it to international entrepreneurship research. Thereby, this paper allows effective testing of key propositions developed in the 
effectuation literature (Sarasvathy 2001; Sarasvathy et al. 2003). Here, INVC processes provide a suitable context, since firms face situations involving different degrees of uncertainty, which impacts on their chosen decision-making processes.

\section{International new venture creation}

International new venture creation as a process

Originating in entrepreneurship theory, the concepts of causation and effectuation have been developed to describe entrepreneurial processes (Sarasvathy 2001). Framed as a "general theory of decision-making in uncertain situations" (Sarasvathy 2008 , p. 227) that highlights human action as the "predominant factor shaping the future" (Sarasvathy 2008, p. 87), she defines (Sarasvathy 2001, p. 245): "Causation processes take a particular effect as given and focus on selecting between means to create that effect. Effectuation processes take a set of means as given and focus on selecting between possible effects that can be created with that set of means."

Effectuation theory has been applied in fields such as management (Augier and Sarasvathy 2004), economics (Dew et al. 2004), finance (Wiltbank et al. 2009), marketing (Read et al. 2009a), and R\&D management (Brettel et al. 2012). Effectuation theory may also be particularly suitable as a building block for internationalization theory, as internationalization can also be framed as a decision-making problem under uncertainty (Jones and Coviello 2005; Schweizer et al. 2010). The connection between internationalization and entrepreneurship is highlighted in the work of Jones and Coviello (2005), who conceptualize internationalization as an "entrepreneurial process of behavior in time" (p. 284) and frame INVC as a process under uncertainty.

This explicit introduction of decision-making under uncertainty makes effectuation a welcome addition to established internationalization theories that do not emphasize this particular aspect. Whitelock (2002) analyzes a range of internationalization theories, including the eclectic paradigm (Dunning 1988), transaction cost analysis (Erramili and Rao 1993), what she labels as the interactive network approach (Turnbull 1987), and the business strategy approach (Welford and Prescott 1994). She finds all of these approaches fail to effectively capture decision-making under uncertainty because "each of the theories presented above is dependent to some extent on the existence of market information to inform internationalization decisions" (p. 344-345). McDougall et al. (1994) discuss monopolistic advantage theory, product cycle theory, stage theory of internationalization, oligopolistic reaction theory, and internalization theory and state that they have the common shortcoming of tending to "ignore the individual and small group level of analysis (i.e., the entrepreneur and his or her network of business alliances)" (p. 469).

Decision-making under uncertainty and a focus on the entrepreneur have recently been integrated in internationalization theory. In the ground-breaking work by Johanson and Vahlne (1977), the authors argued that the internationalization process is affected by limited knowledge about the international market (that is, uncertainty), eventually addressed by actually conducting operations abroad. In a recent extension of their 1977 model, Johanson and Vahlne (1977) emphasize the concept of 
"opportunity" by elaborating on the concept of "knowledge" in their model. They state (Johanson and Vahlne 2009, p. 1424): "opportunities constitute a subset of knowledge. [...] we consider opportunities to be the most important element of the body of knowledge that drives the [internationalization] process." Drawing on opportunity theory, they recognize that opportunities can be discovered as well as created by the entrepreneur.

The entrepreneur as an actor became more central in the Johanson and Vahlne's models. For the 1977 model, the authors (Johanson and Vahlne 1977, p. 23) stated: "[...] for this time being, [we] disregard the decision style of the decision maker." In their 2009 model, they explicitly recognize managerial discretion, particularly regarding the discovery and creation of opportunities in a network context. This development was continued by Schweizer et al. (2010), who explicitly introduce entrepreneurial capabilities and the exploitation of opportunities in their entrepreneurial process model of internationalization. Schweizer et al. (2010) emphasize the individual level of analysis; they explicitly incorporate effectuation theory in an attempt to model decision-making under uncertainty.

Based on the apparent neglect of decision-making under uncertainty in a number of internationalization theories, and based on a number of promising theoretical developments and qualitative analyses (Schweizer et al. 2010), it could be argued that entrepreneurship in general and effectuation in particular could contribute a relevant theoretical component to internationalization theory. More specifically, based on the work by Sarasvathy (2001), Chandler et al. (2009) provide a framework contrasting causation and effectuation along the lines of goal definition, key decision parameters, dealing with uncertainty, and basis of exploitation (see Table 1).

In effectuation, goals emerge in the course of the process, whereas in causation, goals are defined prior to decision-making. An example of emergent goals is provided by Sarasvathy's (2001) "Curry in a Hurry" thought experiment that illustrates how goals emerge as an entrepreneur reacts to environmental contingencies. Examples of predefined goals are regularly found in traditional business planning literatures, which portray entrepreneurs starting with a very precise idea of what they are going to market. In internationalization, a company that relies on emergent goals would remain flexible with regard to the strategic goals of an internationalization. Companies relying on defined goals would have a fixed plan concerning where to go (international market selection), how to go (entry mode selection), and what to achieve in the international market (strategic goals).

Table 1 Key characteristics of causation and effectuation

\begin{tabular}{lll}
\hline & Causation & Effectuation \\
\hline Goals are ... & Pre-defined & Emerging \\
Decision parameters include ... & Maximization of expected return & Affordable loss \\
Dealing with uncertain future through .... & Business planning and & Pre-commitment and \\
& competitive analysis & alliances \\
Exploitation of ... & Capabilities and resources & $\begin{array}{c}\text { Environmental } \\
\text { contingencies }\end{array}$ \\
\hline
\end{tabular}

Based on Chandler et al. (2009) 
According to the affordable loss principle, effectuators tend to make decisions that, if they fail, they would not put the existence of the venture at stake: under this principle, investments are made incrementally. Conversely, companies that focus on causation would instead seek to maximize expected returns and to invest a large up front sum. This means that in internationalization, effectuators then would progress incrementally, whereas firms that rely on causation would internationalize immediately.

When dealing with uncertainty, effectuators negotiate pre-commitments from stakeholders, such as contracts guaranteeing stable future sales levels, thereby trying to "control an unpredictable future." Entrepreneurs that rely on causation, on the other hand, deal with uncertainty by trying to plan ahead by using business planning and competitive analysis. In internationalization, effectuators would for example exhibit a "follow-the-customer" behavior (Eriksson et al. 2000; Erramilli and Rao 1993), whereas firms that rely on causation would trust their own market analyses.

Effectuators flexibly exploit contingencies that arise as the new venture unfolds: Sarasvathy's Curry in a Hurry experiment neatly illustrates this behavior. Entrepreneurs that rely on causation, on the other hand, tend to exploit current capabilities and resources, reminiscent of the "administrative" behavior in Stevenson's conceptualization of Entrepreneurial Management (Stevenson and Jarillo 1990). When internationalizing, effectuators would embrace opportunities that emerged subsequently, whereas firms that rely on causation would tend to engage in international activities matched by their current capabilities.

Causation- and effectuation-based approaches to international new venture creation

Previous empirical literature on causation and effectuation in international entrepreneurship is relatively rare, owing to the novelty of effectuation theory in general, the novelty of the operationalization of $\mathrm{C} \& \mathrm{E}$ in particular, and the relative scarcity of factor models in INVC literature (Perry et al. 2012). Nevertheless, it is possible to identify some applications of C\&E in extant literature.

In IB textbooks, internationalization is modeled as a series of steps: choosing a target market, setting goals, selecting the entry mode, tactical and operational planning for market entry, and finally entry in to market (e.g., Root 1994). This sequential approach is premised upon the assumption that decision makers are fully informed about the decision parameters, allowing them to plan rationally and arrive at a benefitmaximizing choice of entry mode (Maignan and Lukas 1997). This process resembles the segmentation, targeting, and position process that, as Sarasvathy (2001) indicated, characterizes causation-based market entry processes.

Causation-based approaches to INVC were observed in a variety of studies. For example, Brewer (2001) found a linear "planned" approach in which countries are selected based on a rational assessment of market attractiveness and the firm's potential competitive position. In the same vein, Brouthers and Nakos (2005) found that firms using systematic international market selection outperform firms that select their markets in an ad hoc way. Beyond market selection, Lukas et al. (2007) draw on the literature on export planning to point out that formalized export planning is positively related to export performance.

In contrast to normative, rational approaches to INVC, researchers have now begun to highlight the fact that decision makers are not fully rational in the INVC 
process, but that mental models (Maignan and Lukas 1997) and cognitive maps (Andersen and Strandskov 1997) exert a large influence. Mental models are simplified representations of reality that help decision-makers to make sense of empirical reality. Maignan and Lukas (1997) reported for example that managers did not use a "comprehensive, deliberate analysis" to make market entry decisions. Rather, mental models about the origins of a firm's competitive advantage were used to shape the selection of entry modes. By way of illustration, those firms that have a mental model focused on customer orientation may analyze in detail customer demand in foreign markets and thereby neglect other sources of information.

Another stream of research highlights the emergent nature of INVC processes. Crick and Spence (2005) reported results from case studies in which entrepreneurs have mentioned that they have internationalized based on a chance encounter during their vacation, a class reunion, or based on hiring a manager that happened to have an international network. Moreover Çalişkan et al. (2006) highlight the serendipitous roots of INVC processes. Entrepreneurs might not have the time to engage in careful information gathering and rational planning, particularly in dynamic markets in hightech fields. By reacting to opportunities, they effectively adopt emergent strategies (Crick and Spence 2005). Mainela and Puhakka (2009) focus explicitly on the role of effectuation in INVC and find instances of affordable-loss bearing and partnering (an effectual way of dealing with uncertainty) in the INVC process of setting up an international joint venture.

\section{A process model of causation and effectuation in INVC in SME}

\section{Illustrating the model}

While the preceding literature review has shown that both causation-based and effectuation-based elements exist in INVC processes, key antecedents and consequences of $\mathrm{C} \& \mathrm{E}$ in internationalization remain unexplored. To explore antecedents and consequences of $\mathrm{C} \& \mathrm{E}$, an empirical test is used, applying a model starting with a general decision to internationalize. At this point, the entrepreneur then makes a choice between using a causation-based or effectuation-based decision-making process. The choice of process is influenced by task-specific experience and perceived uncertainty concerning the initial target country (Sarasvathy et al. 2003). Finally, the type of INCV processes which was chosen then impacts on the approach to internationalization, most notably the entry mode selection (Fig. 1).

Causation and effectuation may not be entirely exclusive choices. On one hand, the literature discusses the concepts as if they were diametrically opposed, with entrepreneurs having to choose either causation or effectuation. Chandler et al. (2009) do indeed find that causation correlates positively with core aspects of effectuation such as affordable loss and pre-commitment. Hence, it may, for example, be possible that a factor that positively impacts on the degree to which effectuation is used also positively impacts on the use of causation. Therefore, the hypotheses are formulated and analyses are performed separately for both causation and effectuation. 


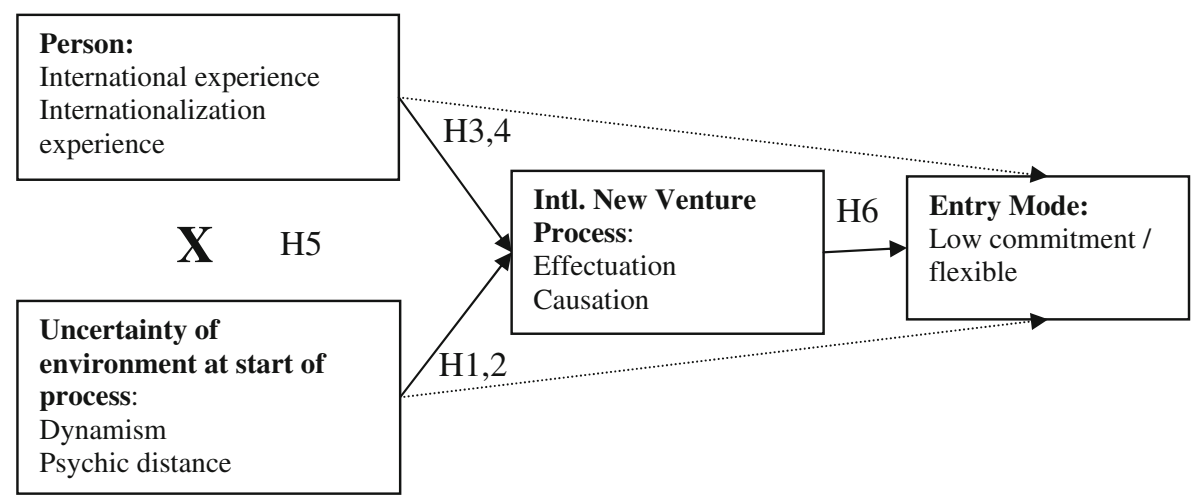

Fig. 1 The new international venture creation process

\section{Antecedents to causation- or effectuation-based INVC}

While causation is said to be more effective in environments where the future is easy to predict, effectuation may be more effective in unpredictable circumstances (Sarasvathy 2001). A key element of predictability is the psychic distance, here defined as "the individual's perception of the differences between the home country and the foreign country" (Sousa and Bradley 2006, p. 51). The higher the degree of psychic distance, the more unfamiliar the entrepreneur is with the particular foreign market (Shane et al. 1995; Slangen and van Tulder 2009), which increases uncertainty in decision-making (Tihanyi et al. 2005). Hence, under conditions displaying a large degree of psychic distance, managers realize that causation-based INVC processes may not be effective. Rather than trying to predict an unknowable future (Sarasvathy 2001), entrepreneurs may adopt an effectuation approach to exploit opportunities as they arise (Dow 1999).

H1a The larger the psychic distance of the entrepreneur with regard to the initial target market, the more likely entrepreneurs will rely on effectuation.

H1b The larger the psychic distance of the entrepreneur with regard to the initial target market, the less likely entrepreneurs will rely on causation.

A further element within predictability is the perceived dynamism of the foreign market. Dynamism refers to the speed and the qualitative degree of changes in the market (Dess and Beard 1984). Highly dynamic markets change rapidly and often in unexpected ways. In these situations, causation-based INVC processes might not be feasible. Firstly, formal business planning requires input data that can be forecasted with a certain amount of accuracy. Secondly, formal business planning might be time consuming to the degree that contingencies cannot realistically be exploited in a timely way because the "window of opportunity" (Abell 1980) has already closed. This finding is underscored by Gruber (2007) who argues that the performance impact of business planning is negative particularly in dynamic environments.

$\mathrm{H} 2 \mathrm{a}$ The larger the perceived dynamism of the foreign market, the more likely entrepreneurs are to rely on effectuation.

$\mathrm{H} 2 \mathrm{~b}$ The larger the perceived dynamism of the foreign market, the less likely entrepreneurs are to rely on causation. 
The amount of task-specific experience is a key antecedent to the choice of either causation-based or effectuation-based NVCPs (Dew et al. 2009; Read et al. 2009b). Dew et al. in particular show that more experienced entrepreneurs are more likely to use effectuation than causation. In a protocol analysis of a hypothetical new venture creation process, expert entrepreneurs were more likely to use means-driven rather than ends-driven action, consider affordable loss rather than expected return, and use partnerships rather than competitive analysis.

As the theoretical foundation for these findings, Dew et al. (2009) draw on the literature on expert versus novice decision-making. They point out that experts are more likely to use analogical rather than analytical decision-making (Sloman 1996), think in a more holistic and conceptual way, and weigh predictive information more critically. They argue that differences in the number and accessibility of experiences, representations and organization of knowledge, and critical stances to predictive information are the drivers of these differences.

Analogical reasoning is based on finding associations based on knowledge generated from personal experience. It is associated with creativity and imagination. Conversely, analytical reasoning is based on causal, logical, and hierarchical relations based on knowledge from language and formal systems, usually associated with explanation and formal analysis (Sloman 1996). These features make analogical reasoning more likely to be used in means-driven situations, since these situations may have more degrees of freedom. People using analogical reasoning may be less reliant upon competitive analysis and be more skeptical of predictive reasoning. At the same time, they may be more willing to embrace the creative use of contingencies as they arise.

The capacity of being an expert is often confined to specific fields of experience and knowledge. Therefore, not every type of business experience or entrepreneurial experience will impact on the type of decision-making in internationalization. Rather, it is both international and internationalization experience that may impact on the degree to which effectuation-based INVC processes are adopted.

H3a The greater the international experience of the entrepreneurs, the more likely entrepreneurs are to rely on effectuation.

$\mathrm{H} 3 \mathrm{~b}$ The greater the international experience of the entrepreneurs, the less likely entrepreneurs are to rely on causation.

$\mathrm{H} 4 \mathrm{a}$ The greater the internationalization experience of the entrepreneurs, the more likely entrepreneurs are to rely on effectuation.

$\mathrm{H} 4 \mathrm{~b}$ The greater the internationalization experience of the entrepreneurs, the less likely entrepreneurs are to rely on causation.

The decision to rely on effectuation is driven by both perceived uncertainty and by experience. Experienced entrepreneurs, who would tend to be effectuators, may, in predictable environments, also choose to use causation-based approaches, as they may be aware of the benefits of formal planning under these conditions (Gruber 2007), while in unpredictable environments, they are likely to realize the futility of trying to forecast the future. Inexperienced entrepreneurs in predictable environments may find it easy to follow textbook-type causation-based internationalization scripts and might also realize the limits of forecasting and rational planning in unpredictable 
environments, but because they lack experience, they are less likely to adopt effectuation-based INVC.

H5a The degree of uncertainty moderates the relationship between experience and the degree to which effectuation is used: the more uncertain the environment, the stronger the positive relationship between experience and the degree to which effectuation is used.

$\mathrm{H} 5 \mathrm{~b}$ The degree of uncertainty moderates the relationship between experience and the degree to which causation is used: the less uncertain the environment, the stronger the relationship between experience and the degree to which causation is used.

Entry mode selection of causation- and effectuation-based INVC

One of the key decisions involved in internationalization is the entry mode selection (Canabal and White 2008). Because the entry mode choice is irreversible and has long-term consequences for the company (Morschett et al. 2010), research on this decision has become an important stream in the IB literature (Werner 2002). The entry mode is the institutional arrangement that a firm chooses for entering into an international market (Anderson and Gatignan 1986). Institutional theory distinguishes three modes, namely, market, hybrid, and organizational (Brouthers and Hennart 2007), which can be organized "along a continuum of increasing control, commitment, and risk" (Brouthers and Hennart 2007, p. 397). Exports (market mode) are on one end of the continuum, hybrid forms such as contractual cooperations (hybrid) in the middle, and wholly owned subsidiaries (organization) as the most risky and resource intensive are on the other end.

As effectuation-based NVC emphasizes affordable loss, flexibility, and precommitment through network building, these characteristics will be reflected in the international entry mode selection as well. There is evidence of internationalization behavior reflecting some of the elements of effectuation. Firstly, firms tend to "follow the customer" who goes abroad (Eriksson et al. 2000; Erramilli and Rao 1993; Madsen and Servais 1997). This behavior illustrates the importance of precommitment and may also be a consequence of basing decision-making on affordable losses. Secondly, there is evidence of a high degree of customer orientation in "born global" firms (Madsen and Servais 1997). As firms with a high degree of customer orientation react flexibly to customer demands, this can be an indicator for the importance of flexibility in internationalization.

H6a The more the INVP is characterized by effectuation, the more likely entry modes with a low degree of resource commitment and with a high degree of flexibility are chosen, such as exporting.

H6b The more the INVP is characterized by causation, the more likely entry modes with a high degree of resource commitment and with a low degree of flexibility are chosen, such as equity-based entry modes.

The age and the size of the firm are used as control variables. The link between firm age and a tendency to choose either effectual or causational new venture creation processes is ambiguous. On the one hand, older firms may have a larger degree of 
task-specific knowledge, making effectuation more likely (see hypotheses 3a and $3 \mathrm{~b}$ ). On the other hand, older firms might exhibit a larger degree of formality in decisionmaking, making causation more likely. International market entry by older firms could be based on a formalized decision-making process, which follows a causation logic: Rialp-Criado et al. (2010) show that the strategy-making process in the context of internationalization follows a firm maturity life cycle from entrepreneurialvisionary to planning-analytical. Miller (1983) argued that decisions/entrepreneurial orientation is driven by intuitive strategy-making in smaller, "simple" firms and by formalized planning in larger firms. A second set of control variables is introduced relating to the link between INVC processes and entry mode selection. It can be assumed that young and small firms will have a propensity towards exporting, as young and small firms may lack the resources and the capabilities to select any other entry mode, even though they might otherwise so be inclined.

\section{Method}

\section{Sample}

This study is based on a sample of rapidly growing small and medium enterprises (SMEs), the finalists of the German "Entrepreneur of the Year" contest 2010. Gazelles are here defined as high-growth independent and owner-managed firms (with unity of ownership, liability, and leadership, Hamer 1990). The definition of the IfM was adopted (Wolter and Hauser 2001), defining SMEs as firms with more than 10 and less than 500 employees. The decision to focus on gazelles was made because these firms internationalize at a fast pace. For example, the entrepreneurs report that the last completed INVC processes began with a first idea on average 3 years before the survey, with first actions having been taken on average 2 years before the survey. While this may seem a long time span, this is much shorter than the time span that would be found in a random sample of internationalizing SME.

This contest is open to all owner-managed firms with a proven track record of organic growth registered in Germany. Data were gathered by a mailed survey addressed to the CEOs, regarded as the most competent providers of valid data and best informed regarding a firm's financial and time investments in internationalization. Where possible, the information obtained was scrutinized and triangulated using publicly available data, and no data differences were found. Sixty-five companies participated in the 2010 contest. As questionnaire completion was obligatory for the contest, there were no missing cases. Missing data were imputed with the EM algorithm.

Operationalization

\section{Antecedents}

International experience is reflected in the numbers of years spent abroad, both for business or educational purposes. As there was no reason to weigh one component over the other, these two items were integrated to an unweighted additive score. 
Internationalization experience is reflected in the number of international new market entries that the entrepreneur participated in the last 3 years. The analysis was repeated using the absolute number of international market entries of the company as a robustness test.

Psychic distance is comprised of perceived cultural, linguistic, and structural differences (Brewer 2007; O'Grady and Lane 1996). Entrepreneurs were asked of the degree to which they were familiar with these aspects of the initial target country. Exploratory factor analysis with principal component analysis with varimax rotation reveals a single factor explaining $75.16 \%$ of the variance with a Cronbach's alpha of .910. Higher factor values indicate a lower degree of psychic distance between entrepreneur and target country.

Dynamism refers to the degree and magnitude of expected changes in the market (McKelvie et al. 2009). This assessed the degree to which the entrepreneurs perceived the country market to be uncertain prior to the actual market entry. Exploratory factor analysis with principal component analysis and varimax rotation reveals a two-factor solution, with one factor reflecting dynamism of the technical environment and one factor dynamism of the general environment (see Appendix 1).

\section{Process variables: Causation and effectuation}

Operationalizing both causation and effectuation utilized the scale developed by Chandler et al. (2009). In this analysis, respondents were asked to answer the items from Chandler et al. (2009) with regard to their most recent INVC processes. Fivepoint Likert-type scales were used to assess the degree to which respondents agreed with the statement relating to the item. Exploratory factor analysis based on varimax rotation was used to validate the scales. Causation was operationalized with the factor score of the associated items, and effectuation was calculated as an unweighted summed index based on the factor scores of the associated items. The validity of measurement for all constructs can be considered as good (see Appendix 1).

\section{Dependent variable}

The entry mode is operationalized with an ordinal five-step scale, with each step representing increasing resource commitment and decreasing flexibility. The entry modes used are direct exporting/internet, indirect exporting, cooperations, joint ventures, and wholly-owned subsidiaries. The distribution of the variables was highly skewed with $55 \%$ of the companies having chosen exporting and $45 \%$ of the companies having chosen entry modes with more resource commitment and less flexibility. Hence, this variable was dichotomized between exporters and collaborators/ equity-type market entry.

\section{Method of analysis}

Given the model structure, the method of choice would be a structural equation model (SEM). However, the model contains a binary dependent variable, and as SEM does not readily support binary dependent variables, the analysis was performed in two steps. Firstly, hypotheses 1, 2, and 3 were tested with an ordinary least square (OLS) 
regression of the factor scores derived from the operationalization of the endogenous variables. Hypothesis 4 was tested by running a series of moderated regression analyses following Aiken and West (1991). Secondly, a binary logistic regression of the factor scores of personal, environmental, and process-based factors was performed.

\section{Results}

Antecedents to causation and effectuation

For the first part of the analyses, two OLS regressions were calculated. Firm age and size were included as control variables, and personal as well as environmental variables are modeled as antecedents to the choice of causation as against effectuation (Table 2).

The results indicate that psychic distance has a positive relationship with causation $(b=.525$, significant on a level under $1 \%)$, while the relationship with effectuation is not significant. This result runs counter to hypothesis 1 , proposing a positive relationship with effectuation.

The results suggest a nonsignificant relationship between dynamism and causation $(b=-.035, p=.159)$ and a positive, significant relationship between technical dynamism and effectuation $(b=.223)$. Given the small sample size, a significance value of $10 \%$ can be regarded as sufficient. These results partially support hypothesis 2 .

The results show a negative relation between international experience and causation $(b=-.391)$ and a positive relationship with effectuation $(b=.243)$. These results support hypothesis 3 . There is partial support for hypothesis $3 \mathrm{~b}$, in that there is no

Table 2 Antecedents to causation and effectuation

\begin{tabular}{lll}
\hline & Causation & Effectuation \\
\hline Constant & & \\
Age of firm (year of foundation) & $.006(.586)$ & $.038(.768)$ \\
Size (turnover mio. Euro) & $.019(.658)$ & $.122(.179)$ \\
Psychic distance & $.525(.000)^{* * *}$ & $.188(.231)$ \\
Dynamism-technical & $-.035(.758)$ & $.223(.093)^{*}$ \\
Dynamism-general & $.159(.220)$ & $.199(.177)$ \\
International experience & $-.391(.000)^{* * *}$ & $.243(.089)^{*}$ \\
Internationalization experience & $.120(.320)$ & $.292(.042)^{* *}$ \\
& $R^{2}=.480 * * *$ & $R^{2}=.152, \mathrm{n} . \mathrm{s}$. \\
& $d f=65$ & $d f=64$ \\
\end{tabular}

n.s. not significant

$* p<.1, * * p<.05, * * * p<.0001$ 
relationship between internationalization experience and causation $(b=.120)$, but a positive relation between internationalization experience and effectuation $(b=.292)$.

To test the moderation hypothesis, a series of moderated regression analyses was run. In models $1 \mathrm{a}-\mathrm{d}$, moderation of psychic distance and international/internationalization experience was analyzed for causation and effectuation. In models $2 \mathrm{a}-\mathrm{d}$, the same analyses were performed for the moderation effects of technical dynamism, and in models $3 \mathrm{a}-\mathrm{d}$, for the moderation effects of general dynamism.

The results indicate a positive interaction effect between psychic distance and international experience in the model with effectuation as a dependent variable (model 1b, $b=.328$ ), with an increase of explained variance from .152 to .233. While this finding is in line with theory, the finding regarding causation is not (model $1 \mathrm{~b}$, $b=.166)$.

The results indicate a negative interaction effect between technical dynamism and international experience where causation is the dependent variable (model $2 \mathrm{a}, b=$ -.293 ): the stronger the technical dynamism and the more international experience, the less likely the entrepreneurs are to choose causation. While this finding is in line with theory, the finding regarding effectuation is not (model $2 \mathrm{~b}, b=-.231$ ) (Table 3 ).

\section{Effects of causation and effectuation on EMS}

For the second part of the analysis, a binary logistic regression was performed. EMS and $C \& E$ were the dependent and the primary independent variables, respectively. Firm demographics, indicators for uncertainty, and international(-ization) experience were added as control variables (Table 4).

The results from the model indicate that the market entry mode is neither significantly influenced by firm demographics, nor by uncertainty, nor even by experience. The results indicate that entrepreneurs that apply a causation-based INVP are more likely to use export as opposed to equity-related entry modes. The coefficient is significant at the $1 \%$ level. The overall model is significant at the $5 \%$ level. The model correctly predicts $73.8 \%$ of the cases, which is $18.4 \%$ more than in the base model without coefficients.

\section{Discussion and conclusion}

\section{Discussion}

The goal of this research was to analyze antecedents and consequences of effectuation and causation in the international new venture creation process. The first finding was that causation and effectuation do not seem to be diametrically opposed concepts, as shown by a positive correlation between these constructs. The fact that $\mathrm{C} \& \mathrm{E}$ are not opposed leads to more complex analyses: It was insufficient to test the relationships involving only effectuation (or causation). Rather, tests for both INVC process variables had to be performed. It was only possible to fully support this hypothesis if both sub-hypotheses could not be rejected (see Table 5 for an overview).

The first hypothesis stated that the larger the psychic distance, the more an entrepreneur would be inclined to use effectuation rather than causation. The findings 


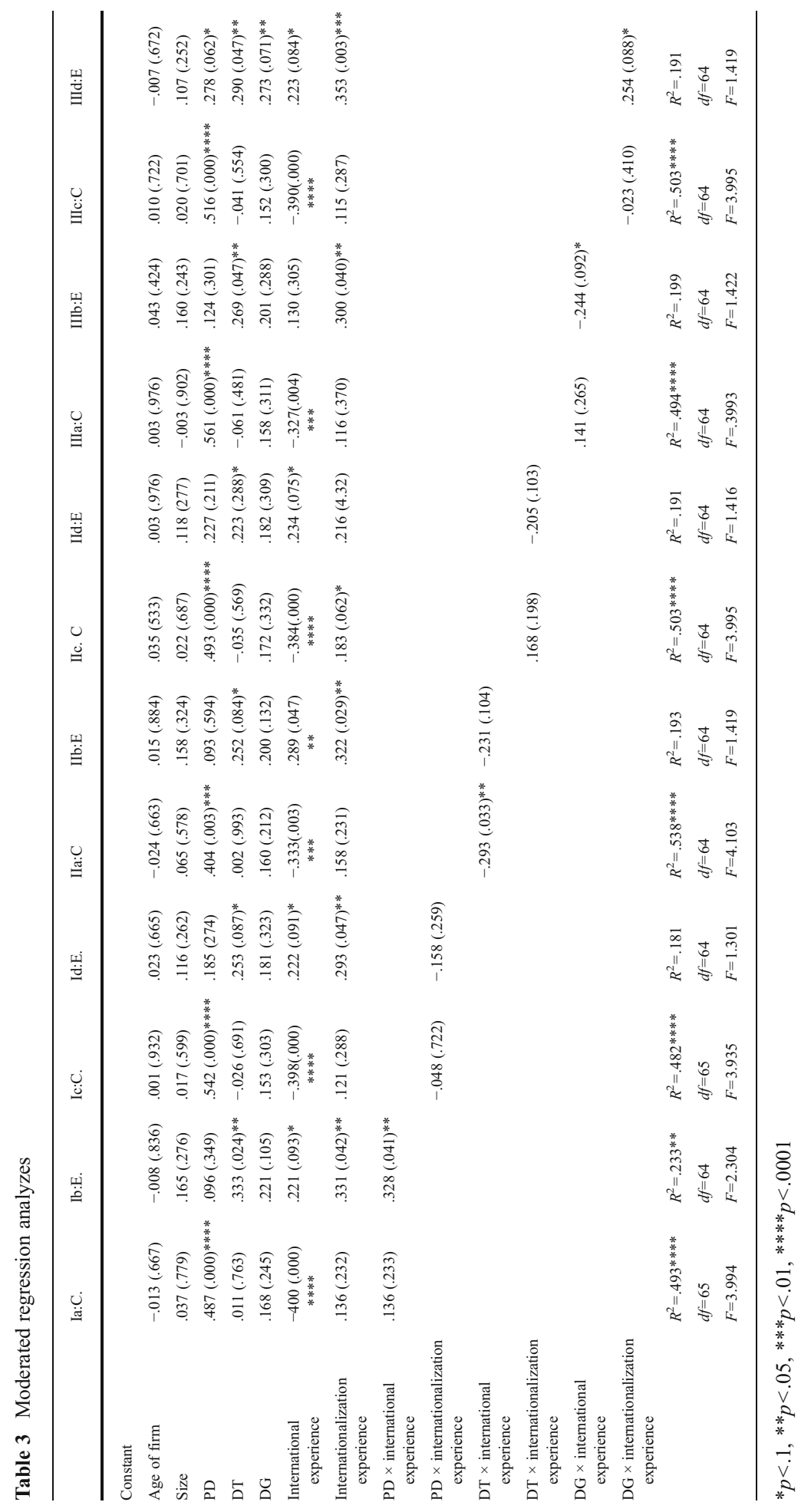


Table 4 Logistic regression: entry mode

\begin{tabular}{llc}
\hline & $B$ & S.E. \\
\hline Age of firm (year of foundation) & .021 & .014 \\
Size (turnover mio. Euro) & .002 & .001 \\
Psychic distance & -.532 & .459 \\
Dynamism-technical & .416 & .380 \\
Dynamism-general & -.435 & .385 \\
International experience & .009 & .035 \\
Internationalization experience & -.061 & .047 \\
Causation & -1.514 & $.565^{* *}$ \\
Effectuation & .216 & .240 \\
\hline
\end{tabular}

Dependent variable: entry mode. 1 export; 2 otherwise; $-2 L L$ 53.864; Cox \& Snell $R^{2}=.324$; Nagelkerke's pseudo $R^{2}=.434 ; \%$ correctly classified $=73.8 \% ; d f=65$

S.E. standard error

however show that a large degree of psychic distance induces entrepreneurs to apply causation. An explanation for this finding is that psychic distance can be regarded by the entrepreneurs as a knowledge gap that can effectively be closed by planning type of behavior. The results indicate that entrepreneurs confronted with (partially) unknown markets start searching for information by engaging in a systematic information search including competitive analysis and marketing planning. The other way around is that it could be possible that in particular in a situation with low psychic distance, such as a regional cross-border cluster, more effectuation could be expected because entrepreneurs in such an environment of intensive knowledge exchange are more exposed to unexpected information flows (Steinle et al. 2007).

The second hypothesis stated that the more dynamic an international market is perceived to be, the more likely entrepreneurs will be inclined to use effectuation, a

Table 5 Summary of the results

\begin{tabular}{|c|c|c|c|c|}
\hline & & Expected & Result & \\
\hline H1a & Psychic distance - effectuation & $\uparrow$ & n.s. & Not confirmed \\
\hline $\mathrm{H} 1 \mathrm{~b}$ & Psychic distance - causation & $\downarrow$ & $\uparrow$ & \\
\hline $\mathrm{H} 2 \mathrm{a}$ & Dynamism-effectuation & $\uparrow$ & $\uparrow$ & Partially confirmed \\
\hline $\mathrm{H} 2 \mathrm{~b}$ & Dynamism - causation & $\downarrow$ & n.s. & \\
\hline $\mathrm{H} 3 \mathrm{a}$ & International experience-effectuation & $\uparrow$ & $\uparrow$ & Confirmed \\
\hline $\mathrm{H} 3 \mathrm{~b}$ & International experience - causation & $\downarrow$ & $\downarrow$ & \\
\hline $\mathrm{H} 4 \mathrm{a}$ & Internationalization experience-effectuation & $\uparrow$ & n.s. & Partially confirmed \\
\hline $\mathrm{H} 4 \mathrm{~b}$ & Internationalization experience-causation & $\downarrow$ & $\downarrow$ & \\
\hline $\mathrm{H} 5 \mathrm{a}$ & Experience $\times$ dynamism: effectuation & + & $(+)$ & Partially confirmed \\
\hline $\mathrm{H} 5 \mathrm{~b}$ & Experience $\times$ dynamism: causation & - & $(-)$ & \\
\hline H6a & Effectuation-export & $\uparrow$ & n.s. & Not confirmed \\
\hline $\mathrm{H} 6 \mathrm{~b}$ & Causation-equity involvement & $\uparrow$ & $\downarrow$ & \\
\hline
\end{tabular}


finding in line with the theory. However, the reverse was not supported, namely, that entrepreneurs in dynamic markets are less likely to follow causation-type approaches. Some entrepreneurs in dynamic markets may back up their effectuated INVC processes with systematic information search (indicating a higher degree of causation), while other entrepreneurs may refrain from so doing, thereby leading to a nonsignificant overall effect.

The third hypothesis stated that entrepreneurs with a large degree of international experience tend to use effectuation rather than causation, and there was full support for this hypothesis. However, international experience and internationalization experience seem to have a slightly different effect in that entrepreneurs with more internationalization experience do not necessarily use more effectuation-based approaches, lending only partial support to hypothesis 4 . It might be that taskspecific experience is not greatly enhanced by taking part in multiple internationalization episodes, as the diversity and idiosyncrasy of experiences gained from INVC processes may impede learning from these situations. In addition, Morrish (2009) argues that portfolio entrepreneurs tend to use effectuation in the early stages of portfolio building, and causation at later stages, which runs counter to the argument that more experienced entrepreneurs tend to engage in effectuation processes.

The fifth hypothesis received limited support: Experience and uncertainty are mutually reinforcing in a way that experienced entrepreneurs in uncertain environments exhibit more effectuation and less causation. Firstly, entrepreneurs with a high degree of international experience, when faced with situation of psychic distance, tend to apply more effectuation (model 1b). Based on the (so far unproven) premise that effectuation is the more effective way to proceed in unknown circumstances, this suggests that previous international experiences have taught entrepreneurs that effectuation is a viable strategic option. Secondly, entrepreneurs with a high degree of international experience seem to apply significantly less causation when faced with a high degree of technical uncertainty (model 2a). Again, previous experience may have shown entrepreneurs that causation is not viable when the degree of technical dynamism is high. While these findings (model $1 \mathrm{~b}$ and model $2 \mathrm{~b}$ ) support existing theory, it remains to be discussed why (a) the findings only apply on one type of uncertainty each and (b) why the developments for effectuation are not mirrored by those for causation.

Finally, we expected that entrepreneurs who use more effectuation would tend to use exporting-based entry modes, while causation-based INVC processes would lead to market entry modes with greater equity involvement. The results indicate that effectuation does not predetermine any entry mode strategy, while entrepreneurs who use causation tend to use less equity type (and more export) entry modes.

\section{Conclusion}

The first contribution to entrepreneurship theory is that this research extends the context of effectuation and causation to encompass corporate international entrepreneurship, thus demonstrating broader applications for these theoretical concepts. On the operational level, the largely successful attempt to revalidate the scales of Chandler et al. (2009) may encourage researchers to also apply them appropriately 
in their own research contexts. So doing has not hitherto been obvious, given that $\mathrm{C} \& \mathrm{E}$ were originally developed with independent new ventures in mind, demonstrated by Sarasvathy (2001) and the research context in which the scales of Chandler et al. (2009) were developed.

The second contribution to entrepreneurship theory is to indicate that the concepts need not be diametrically opposed, and companies seem to be able to use both to a large extent. This raises the question of how this is possible, whether they can both be used simultaneously, and if so, how? Can they both be used in the same INVC process, but in a temporal sequence, such as suggested by Laaksonen et al. (2010)? Connected to these would be questions relating to the antecedents and (performance) consequences of different combinations of C\&E (Read et al. 2009b).

The third contribution to entrepreneurship theory is the confirmatory test of key correlates of C\&E. Previous evidence from case studies or from other contexts (Brettel et al. 2012) did not analyze the same constructs that were used here. While case studies provide rich, in-depth descriptions of a phenomenon, researchers may remain skeptical about the generalizability of case study findings. This quantitative analysis provides the first (at least partly) generalizable evidence with regard to C\&E.

The first contribution to the international business literature was to show that decision-making processes do matter in international business, thereby making effectuation theory an addition to established internationalization theories. In particular, this research showed that firms who use causation tend to follow exporting-based entry modes. This finding is relevant in that entrepreneurs who are inclined to use causation may forego business opportunities that reside in network or wholly owned subsidiary-type entry modes. A second contribution to the international business literature is derived from the finding that psychic distance is related to causationtype behavior. This calls into question the type of uncertainty with which psychic distance is associated. It seems that entrepreneurs perceive psychic distance more as an information gap that they can try to close with formal planning than as a fundamental uncertainty. Future research could clarify this issue.

As a shortcoming, the usage of gazelle firms as the population may be questioned. While gazelles were chosen so as to limit the recall bias, the populations might still impede generalizing the findings. On one hand, gazelles are different from other firms in that they exhibit high growth; they might not be so different from slower growth firms (Harms 2009). On the other hand, research needs to be contextualized (Zahra 2007), and findings should be replicated in other organizational or cultural contexts.

A further shortcoming is that both the antecedents and process variables were measured ex post. This can lead to post hoc rationalizations and difficulties in recalling the degree of psychic distances that were present when the INVC processes began. Selecting the most recent INVC processes minimized this recall error, but it may nevertheless have still been present. By explicitly pointing out in the item formulation that the entrepreneur may know more after the internationalization process, we tried to relieve the pressure to act in a potentially socially desirable way by understating psychic distance (Dow and Ferencikova 2010). A final shortcoming is the low reliability of the "affordable loss" and "dynamism" variables. Future research is encouraged, particularly with regard to the measurement of causation and effectuation.

More studies on the nature of the entrepreneurial process are therefore certainly warranted (Moroz and Hindle 2012). A first justification for this call lies in a general 
criticism of current entrepreneurial process models (Moroz and Hindle 2012) in general, and a "translation" of process-dynamic type of theories (such as effectuation theory) across to a static framework type of research, as notably happens when effectuation's temporal dimension is omitted by the research approach (Buttriss and Wilkinson 2006). Consequently, there is the option to use longitudinal research designs with multiple cross-sections to capture varying degrees of causation and effectuation over time (van de Ven and Huber 1990). A second justification is the finding that there are also companies that succeeded in setting up an international new venture, but for which their entrepreneurial process can be neither be described in terms of causation nor effectuation. The question then follows as to what type of entrepreneurial process they applied.

Future research may also analyze different antecedents and consequences of C\&E in the INVC process, for example on precocity (Zuchella et al. 2007), speed (Oviatt and McDougall 2005), and scope (Vermeulen and Barkema 2002). In these efforts, attempts towards a co-evolutionary perspective (Pajunen and Manula 2008) that encompasses multiple domains (Harms et al. 2009) could illuminate internationalization's multifaceted nature, creating new insights into the process of international new venture creation.

Acknowledgments We would like to thank two anonymous reviewers for their effort. Also, we would like to thank Hamid Etemad who gave us the opportunity to publish in the Journal of International Entrepreneurship. Finally, thanks to Paul Benneworth for thorough editing.

Open Access This article is distributed under the terms of the Creative Commons Attribution License which permits any use, distribution, and reproduction in any medium, provided the original author(s) and the source are credited.

\section{Appendix 1}

Table 6 Operationalization of key variables

\begin{tabular}{|c|c|c|c|}
\hline Items & $\begin{array}{l}\text { Construct }(\alpha) \text {, } \\
\% \text { var. exl' pl. }\end{array}$ & $\begin{array}{l}\text { Factor } \\
\text { loading }\end{array}$ & $\begin{array}{l}\text { Item- } \\
\text { to-total }\end{array}$ \\
\hline $\begin{array}{l}\text { We developed a strategy to best take advantage of resources } \\
\text { and capabilities }\end{array}$ & $\begin{array}{l}\text { Causation, } .828 \\
59.69 \%\end{array}$ & .832 & 695 \\
\hline We designed and planned business strategies & & .907 & .797 \\
\hline $\begin{array}{l}\text { We researched and selected target markets and did meaningful } \\
\text { competitive analysis }\end{array}$ & & .717 & .560 \\
\hline $\begin{array}{l}\text { We had a clear and consistent vision for where we wanted } \\
\text { to end up }\end{array}$ & & .366 & .252 \\
\hline We designed and planned production and marketing efforts & & .912 & .821 \\
\hline $\begin{array}{l}\text { We experimented with different products and/or business } \\
\text { models }\end{array}$ & $\begin{array}{l}\text { Experimentation, } \\
.813,64.29 \%\end{array}$ & .809 & 638 \\
\hline $\begin{array}{l}\text { The product/service that we now provide is essentially the } \\
\text { same }[\ldots] .(r)\end{array}$ & & 669 & .479 \\
\hline $\begin{array}{l}\text { The product/service that we now provide is substantially } \\
\text { different than we first imagined }\end{array}$ & & .874 & .739 \\
\hline
\end{tabular}

different than we first imagined 
Table 6 (continued)

\begin{tabular}{lll}
\hline Items & $\begin{array}{l}\text { Construct }(\alpha), \\
\% \text { var. exl' pl. }\end{array}$ & $\begin{array}{l}\text { Factor Item- } \\
\text { loading to-total }\end{array}$ \\
\hline
\end{tabular}

We tried a number of different approaches until we found

a business model that worked

We were careful not to commit more resources than we could afford to lose

\begin{tabular}{|c|c|c|}
\hline \multirow{3}{*}{$\begin{array}{c}\text { Affordable loss, } \\
.584,57.80 \%\end{array}$} & .875 & .482 \\
\hline & .905 & .576 \\
\hline & .150 & .275 \\
\hline \multirow{4}{*}{$\begin{array}{l}\text { Flexibility, } \\
.832,67.42 \%\end{array}$} & .860 & .740 \\
\hline & .696 & .853 \\
\hline & .797 & .799 \\
\hline & .915 & .703 \\
\hline \multirow{2}{*}{$\begin{array}{c}\text { Pre-commitment, } \\
.855,87.42 \%\end{array}$} & .935 & .748 \\
\hline & .935 & .748 \\
\hline \multirow{5}{*}{$\begin{array}{c}\text { Psychic distance, } \\
.910,75.16 \%\end{array}$} & .863 & .741 \\
\hline & .891 & .824 \\
\hline & .929 & .867 \\
\hline & .799 & .686 \\
\hline & .874 & .796 \\
\hline \multirow{2}{*}{$\begin{array}{l}\text { Dynamism, tech., } \\
.64073 .54 \%\end{array}$} & .858 & .471 \\
\hline & .858 & .471 \\
\hline \multirow{2}{*}{$\begin{array}{l}\text { Dynamism, general, } \\
.423,63.5 \%\end{array}$} & .797 & .270 \\
\hline & .797 & .270 \\
\hline
\end{tabular}

We were careful not to risk more money than we were willing to lose with our initial idea

We were careful not to risk so much money that the company would be in real trouble

We allowed the business to evolve as opportunities emerged

We adapted what we were doing to the resources we had

We were flexible and took advantage of opportunities as they arose

We avoided courses of action that restricted our flexibility and adaptability

We used a substantial number of agreements [...] to reduce the amount of uncertainty

We used pre-commitments from customers and suppliers as often as possible

I was able to speak the language of the target country fluently

I was well acquainted with the culture of the target country

I was well acquainted with the business habits of the target county

I was well at ease with the people from that target country

I had the feeling that I needed to learn much more about the target country $(r)$

Future technical innovations will be incremental

Type and source of technical innovations $[\ldots]$ are predictable

Demand of our products will fluctuate, but only moderately

We are well aware of the demands of our customers and find it easy to predict changes

\section{References}

Abell DF (1980) Defining the business: the starting point of strategic planning. Prentice-Hall, Englewoods Cliffs

Aiken LS, West SG (1991) Multiple regression: testing and interpreting interactions. Sage, Newbury Park

Andersen PH, Strandskov J (1997) International market selection. J Glob Mark 11(3):65-84

Anderson E, Gatignan H (1986) Modes of foreign entry: a transaction cost analysis and propositions. J Int Bus Stud 17(3):1-26

Augier M, Sarasvathy SD (2004) Integrating cognition, evolution, and design: extending Simonian perspectives to strategic organization. Strateg Organ 2(2):169-204

Brettel M, Mauer R, Engelen A, Küpper D (2012) Corporate effectuation: Entrepreneurial action and its impact on R\&D project performance. J Bus Ventur 27(2):167-184

Brewer P (2001) International market selection: developing a model from Australian case studies. Int Bus Rev 10(2):155-174 
Brewer PA (2007) Operationalizing psychic distance: a revised approach. J Int Mark 15(1):44-66

Brouthers KD, Hennart J-F (2007) Boundaries of the firm: insights from international entry mode research. J Manag 33(3):395-425

Brouthers KD, Nakos G (2005) The role of systematic international market selection on small firms' export performance. J Small Bus Manag 43(4):363-381

Buttriss GJ, Wilkinson IF (2006) Using narrative sequence method to advance international entrepreneurship theory. J Int Entrep 4(4):157-174

Bygrave WD (2004) The entrepreneurial process. In: Bygrave WD, Zacharakis A (eds) The portable MBA in entrepreneurship. Wiley, Hoboken

Çalişkan A, Joern A, Meijnen M, von Moers F, Schapmann F (2006) The first steps of internationalisation for SMEs: serendipitous or intentional? Int J Glob Small Bus 1(3):301-318

Canabal A, White GO (2008) Entry mode research: past and future. Int Bus Rev 17(3):267-284

Chandler GN, DeTienne DR, McKelvie A, Mumford TV (2009) Causation and effectuation processes: a validation study. J Bus Ventur 26(3):375-390

Crick D, Spence M (2005) The internationalisation of 'high performing' UK high-tech SMEs: a study of planned and unplanned strategies. Int Bus Rev 14(2):167-185

Dean JW, Sharfman MP (1996) Does decision process matter? A study of strategic decision-making effectiveness. Acad Manag J 39(2):368-396

Dess GG, Beard DW (1984) Dimensions of organizational task environments. Adm Sci Q 29(1):5273

Dew N, Sarasvathy SD, Venkataraman S (2004) The economic implications of exaptation. J Evol Econ 14 (1):69-84

Dew N, Read S, Sarasvathy SD, Wiltbank R (2009) Effectual versus predictive logics in entrepreneurial decision-making: differences between experts and novices. J Bus Ventur 24(4):287-309

Dow D (1999) A note on psychological distance and export market selection. J Int Mark 8(1):51-64

Dow D, Ferencikova S (2010) More than just national cultural distance: testing new distance scales on FDI in Slovakia. Int Bus Rev 19(1):46-58

Dunning JH (1988) The eclectic paradimg of international production: a restatement and some possible extensions. J Int Bus Stud 19(1):1-31

Eriksson K, Johanson J, Majkgard A, Sharma DD (2000) Effect of variation on knowledge accumulation in the internationalization process. Int Stud Manag Organ 30(1):26-44

Erramilli MK, Rao CP (1993) Service firms' international entry-mode choice: a modified transaction-cost analysis approach. J Mark 57(3):19-38

Gruber M (2007) Uncovering the value of planning in new venture creation: a process and contingency perspective. J Bus Ventur 22(6):782-807

Hamer E (1990) Das mittelständische Unternehmen. Eigenarten, Bedeutung, Risiken und Chancen. Stuttgart: Poller

Harms R (2009) A multivariate analysis of the characteristics of rapid growth firms, their leaders, and their market. J Small Bus Entrep 22(4):429-454

Harms R, Kraus S, Schwarz EJ (2009) The suitability of the configuration approach in entrepreneurship research. Entrep Reg Dev 21(1):25-47

Johanson J, Vahlne J-E (1977) The internationalization process of the firm. A model of knowledge development and increasing foreign market commitments. J Int Bus Stud 8(1):23-32

Johanson J, Vahlne J-E (2009) The Uppsala internationalization process model revisited: from liability of foreignness to liability of outsidership. J Int Bus Stud 40(9):1411-1431

Jones MV, Coviello NE (2005) Internationalisation: conceptualising an entrepreneurial process of behaviour in time. J Int Bus Stud 36(3):284-303

Keupp MM, Gassmann O (2009) The past and the future of international entrepreneurship: a review and suggestions for developing the field. J Manag 35(3):600-633

Laaksonen L, Ainamo A, Karjalainen T-M (2010) Cycles in causation and effectuation: a case study of four metal-music ventures. Paper presented at the High Tech Small Firms Conference, Enschede

Lukas BA, Whitwell GJ, Hill P (2007) Export planning orientation and its antecedents: evidence from exporting it products. J Bus Res 60(12):1282-1289

Madsen TK, Servais P (1997) The internationalization of born globals: an evolutionary process? Int Bus Rev 6(6):561-583

Maignan I, Lukas BA (1997) Entry mode decisions: the role of managers' mental models. J Glob Mark 10 (4): $7-22$

Mainela T, Puhakka V (2009) Organising new business in a turbulent context: opportunity discovery and effectuation for IJV development in transition markets. J Int Entrep 7(2):111-134 
McDougall PP, Shane S, Oviatt BM (1994) Explaining the formation of international new ventures: the limits of theories from international business research. J Bus Ventur 9(6):469-478

McKelvie A, Haynie MJ, Gustavsson V (2009) Unpacking the uncertainty construct: implications for entrepreneurial action. J Bus Ventur 26(11):273-292

Miller D (1983) The correlates of entrepreneurship in three types of firms. Manag Sci 29(7):770-791

Moroz PW, Hindle K (2012) Entrepreneurship as a process: toward harmonizing multiple perspectives. Enterpren Theor Pract. doi:10.1111/j.1540-6520.2011.00452.x

Morrish S (2009) Portfolio entrepreneurs: an effectuation approach to multiple venture development. J Res Mark Entrep 11(1):32-48

Morschett D, Schramm-Klein H, Swoboda B (2010) Decades of research on market entry modes: what do we really know about external antecedents of market entry mode choice? J Int Manag 16(1):60-77

O'Grady S, Lane HW (1996) The psychic distance paradox. J Int Bus Stud 27(2):309-333

Oviatt BM, McDougall PP (2005) Defining international entrepreneurship and modeling the speed of internationalization. Enterp Theory Pract 29(5):537-553

Pajunen K, Manula M (2008) Internationalisation: a co-evolutionary perspective. Scand J Manag 24 (3):247-258

Perry JT, Chandler GN, Markova G (2012) Entrepreneurial effectuation: a review and suggestions for future research. Enterp Theory Pract. doi:10.1111/j.1540-6520.2010.00435.x

Read S, Dew N, Sarasvathy SD, Song M, Wiltbank R (2009a) Marketing under uncertainty: the logic of an effectual approach. J Mark 73(3):1-18

Read S, Song M, Smit W (2009b) A meta-analytic review of effectuation and venture performance. J Bus Ventur 24(6):573-587

Rialp-Criado A, Galván-Sánchez I, Suárez-Ortega S (2010) A configuration-holistic approach to bornglobal firms' strategy formation process. Eur Manag J 28(2):108-123

Root FR (1994) Entry strategies for international markets. Jossey-Bass, San Francisco

Sarasvathy SD (2001) Causation and effectuation: toward a theoretical shift from economic inevitability to entrepreneurial contingency. Acad Manag Rev 26(2):243-263

Sarasvathy SD (2008) Effectuation: elements of entrepreneurial expertise. Edward Elgar, Northampton

Sarasvathy SD, Dew N, Read S, Wiltbank R (2003) Accounting for the future: Psychological aspects of effectual entrepreneurship. Working paper

Schweizer R, Vahlne J-E, Johanson J (2010) Internationalization as an entrepreneurial process. J Int Entrep $8(4): 343-370$

Shane S, Venkataraman S, Macmillan I (1995) Cultural differences in innovation championing strategies. J Manag 21(5):931-952

Slangen AHL, van Tulder RJM (2009) Cultural distance, political risk, or governance quality? Towards a more accurate conceptualization and measurement of external uncertainty in foreign entry mode research. Int Bus Rev 18(3):276-291

Sloman SA (1996) The empirical case for two systems of reasoning. Psychol Bull 119(1):3-22

Sousa CMP, Bradley F (2006) Cultural distance and psychic distance: two peas in a pod? J Int Mark 14 (1):49-70

Steinle C, Schiele H, Mietzner K (2007) Merging a firm-centred and a regional policy perspective for the assessment of regional clusters: concept and application of a "dual" approach to a medical technology cluster. Eur Plan Stud 15(2):235-251

Stevenson HH, Jarillo JC (1990) A paradigm of entrepreneurship: entrepreneurial management. Strateg Manag J 11(5):17-27

Tihanyi L, Griffith DA, Russell CJ (2005) The effect of cultural distance on entry mode choice, international diversification, and MNE performance: a meta-analysis. J Int Bus Stud 36(3):270283

Turnbull PW (1987) A challenge of the stages theory of the internationalization process. In: Rosson PJ, Reed SD (eds) Managing export entry and expansion. Praeger, New York, pp 21-40

Van de Ven AH, Huber GP (1990) Longitudinal field research methods for studying processes of organizational change. Organ Sci 1(3):213-219

Vermeulen F, Barkema HG (2002) Pace, rhythm, and scope: process dependence in building a profitable multinational corporation. Strateg Manag J 23(7):637-653

Welford R, Prescott K (1994) European business: an issue based approach, 2nd edn. Pitman, London

Werner S (2002) Recent developments in international management research: a review of 20 top management journals. J Manag 28(3):277-305

Whitelock J (2002) Theories of internationalization and their impact on market entry. Int Mark Rev 19 (4):342-347 
Wiltbank R, Read S, Dew N, Sarasvathy SD (2009) Prediction and control under uncertainty: outcomes in angel investing. J Bus Ventur 24(2):116-133

Wolter HJ, Hauser HE (2001) In: IfM (ed) Die Bedeutung des Eigentümerunternehmens in Deutschland eine Auseinandersetzung mit der qualitativen und quantitativen Definition des Mittelstands, Jahrbuch zur Mittelstandsforschung. Deutscher Universitäts-Verlag, Wiesbaden, pp 25-77

Zahra SA (2007) Contextualizing theory building in entrepreneurship research. J Bus Ventur 22(3):443452

Zuchella A, Palamara G, Denicolai S (2007) The drivers of the early internationalization of the firm. J World Bus 42(3):268-280 